\title{
The Leisure Behavior of the Turkish Prospective Teachers
}

\author{
Neşe Aslan ${ }^{1} \&$ Belgin Arslan Cansever ${ }^{1}$ \\ ${ }^{1}$ Faculty of Education, Ege University, Izmir, Turkey \\ Correspondence: Belgin Arslan Cansever, Faculty of Education, Ege University, Izmir, Turkey. Tel: \\ 90-232-311-3156. E-mail: belginarslan6@hotmail.com \\ Received: March 14, 2016 \\ doi: 10.5539/hes.v6n2p84
}

\begin{abstract}
This study focused on prospective teachers' leisure behaviors. For this purpose, 47 fourth grade undergraduate students in Faculty of Education in Ege University, Izmir, Turkey participated. A qualitative research design was used in the study. In the process of analysing the data, Greimas'Actant Model as one of the analysing models in Semiology was utilized. This model has been used for the first time in Turkey as an analytical tool applied in leisure literature. It is based on the logical relationships to disaggregate an action into six Actant components. The interview technique assessed the individuals. Miles and Huberman's measurements were used for reliability and validity, and the conformity was found to be $89 \%$. The results of this research study (1) suggest a primary leisure participation in Turkey within the traditional norms and values of society, and (2) within it, the traditional differentiating role for gender.
\end{abstract}

Keywords: leisure participation behavior, Greimas' Actant Model, Turkish prospective teachers, gender

\section{Introduction}

Within the developmental process of industrialization, the enjoyment of leisure has become an important part of the lifestyle of the western societies. Consequently, leisure studies have been the main interest of many researchers, resulting in a significant growth of knowledge about leisure in the pertinent literature. However, in non-western countries, with slower industrial development affecting their culture, leisure awareness has not developed as in western countries. In leisure literature, few studies have been conducted from a non-western perspective (Aslan, 2004, 2005, 2009; Aslan \& Arslan Cansever, 2012; Liu, Yeh, Chick, \& Zinn, 2008; Tsai \& Coleman, 2009). For this reason, several researchers (Chick, 1998; Freysinger \& Kelly, 2000; Shaw \& Henderson, 2005) have drawn attention to this shortage, and encouraged more research to redress this situation. Therefore, we hope that the current research will contribute to the study of the young adults' leisure participation in Turkey, a non-western country.

It is important to note that Turkish society is undergoing a rapid social change from a traditional, rural, and patriarchal society into an increasingly urbanized and industrial one. However, the societal values and attitudes appear to lag behind the changing social structures and functions, and the current perception of leisure may reflect this. A relevant point is that although leisure awareness in Turkish society may not be as developed as in western societies, spending time with the family, which can be considered a leisure activity, has always been valued as a part of the traditional structure (Aslan, 2009; Aslan \& Arslan Cansever, 2012). Additionally, it has been indicated that although Turkish families were involved in very few family leisure activities compared to families in western societies, their involvement was positively related to their satisfaction with family life (Aslan, 2009), which also explains that they enjoyed whatever they did together whether it was called "leisure" or not (p. 171). In another study of Turkish parents (Aslan \& Arslan Cansever, 2012), it was found that parents perceived and valued leisure as spending time with immediate family, other relatives and friends, and participating in a limited variety of home-centered activities. Similar findings were also provided by a study of Turkish women (Aslan, 2004). In conclusion, all of these research studies have a common finding that, as a product of the Turkish collectivist culture, there is a lack of awareness of the concept of leisure.

In addition to the limited research on the Turkish family, parents, and women, leisure participation research of young adults has also been limited. In a study dealing with 420 university students, it was found that only $30 \%$ of them, who were mostly females, participated in leisure activities (Aslan, 2005). Gender has been a chief discriminator in almost all leisure studies, as it was in Turkish youth's involvements in, and constraints to, leisure 
in the above referenced study. Therefore, considering the need for further research on young Turkish adults, this study focuses on the participation in leisure activities of university students (21-22 years old), analyzing it with Greimas' Actant Model, the first such application to educational leisure literature in Turkey. The findings from this study provide insights regarding the relationships between the young adults and their involvement in leisure activities.

\section{Literature Review}

\subsection{Semiotics and the Greimas' Actant Model}

Semiotics is the combination of signs, symbols and signification. Everything represents both itself and something else. Semiotics doesn't inquire about the meaning of a sign, but how meaning is created. The philosophical or logical basis of semiotics depends on constructivism, in which the construct is not equal to its total components. In fact, it is the interaction between the components (Parsa S. \& Parsa A., 2004; Sayin, 2014).

In constructivism and semiotics literature, one of the chief applications has been the Actant Model developed by A. J. Greimas. It is a tool that can theoretically be used to analyze any real or thematized action, but has been used particularly for the action usually depicted in literary texts or images. In fact, this model is the basis of the logical relationships in which an action may be broken down into six components called Actants (Hébert, 2011; Vardar, 2002). These are divided into three opponents, each forming an axis for the Actant description. The axis sought is as follows: subject, and then object. The subject is what is directed toward an object. The relationship between the subject and the object is called junction. Depending on whether the object is conjoined with the subject or disjoined, it is called a conjunction or a disjunction (Hébert, 2011). Following are (1) the descriptions of the axes and (2) a graphic representation of the Actant Model:

-The axis of power: helper and opponent. The helper supports achieving the desired junction between the subject and object, whereas the opponent hinders it.

-The axis of transmission or knowledge: sender and receiver. Sender is the element desiring the establishment of the junction between subject and object. In other words, sender is the encouraging power for the subject to achieve the object (Culler, 2002). The receiver, however, is the element for which the quest is being undertaken. Most of the time, sender and receiver can be the same person or thing. Greimas' conceptual network is generally described in Figure 1 (Arslan Cansever, 2010; Hébert, 2011):

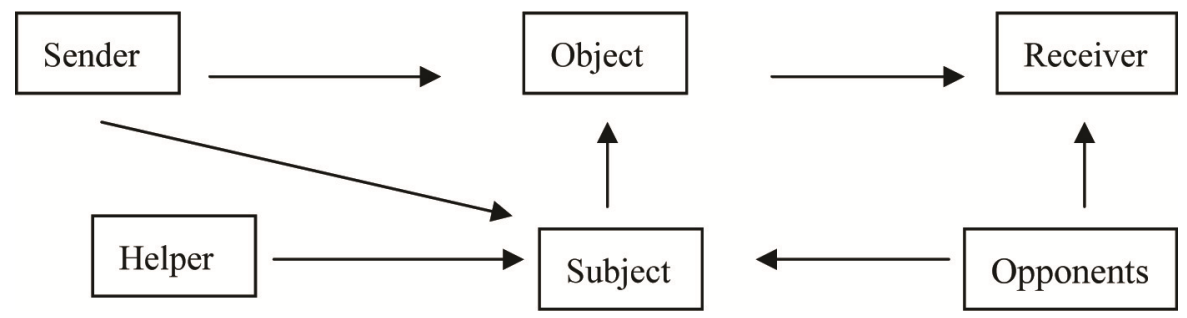

Figure 1. The Actant model of A. J. Greimas

The Actant is not always equal to a character in the traditional way. An Actant may correspond to an anthropomorphic being (i.e., a human, an animal or a thing); or an inanimate element, including things, or a concept. Furthermore, it may be individual or collective (i.e., society) (Hébert, 2011).

Two additional important points should be considered about the Actant Model. First, any concrete Actant is described by a real Actant. For the logic in this Model, the six thematized Actants are based on the relationship of "desire". However, some of these Actants may not be visual or clear. Then, they may be identified by the interpretation of social situations. Second, it is not necessarily expected to find a numerical equivalence between the Actant and its function. For example, the subject may have many more helpers or opponents whereas, an Actant may be both helper or opponent, or even an Actant alone may be conjoining the six Actants in the Model (Arslan Cansever, 2010).

\subsection{Leisure Participation and the Actant Model}

In applying the Actant model to Leisure Participation behavior; the Actants may be motivation, satisfaction, constraints, or negotiation. They may be identified by the interpretation of social situations if they are not visual or clear. 


\subsubsection{Motivation in Leisure Participation}

Leisure, being an element that can be found in any activity, plays an important role in the global society where the rapid development of technology and the increase of workload have resulted in an increase of work stress in individuals. Thus, leisure has become an integral and important part of modern life, which is no longer occupied only by work, and the participation in leisure activities has, then, become an accepted part of life. Jacobs K. and Jacobs L. (2001) state that leisure is regarded as the time given to freely chosen activities performed when not involved in self-care or work. Leisure should result in mastery motivation, self-efficacy, commitment to the activity, and satisfaction. Moreover, leisure is perceived to have short-term benefits, including positive mood, physical fitness, and better structuring of time, as well as the long-term benefits of happiness, health, educational improvements, and social integration ( $\mathrm{Lu} \& \mathrm{Hu}, 2005)$. As such, many people find their leisure more satisfying than their work; leisure can be a major source of pleasure and provide a sense of achievement (Robert, 2001; Chen, $\mathrm{Li}, \&$ Chen, 2013). Humans today have more leisure time than ever in history, but, many people who have a great deal of spare time fail to find satisfying forms of leisure (Agate et al., 2009; Lu \& Kao, 2009).

It has been suggested that one's ability to have a satisfying leisure experience may be related to an individual's motivation to participate in leisure activity (Beggs, Elkins, \& Powers, 2005). An important approach examining what generally motivates an individual to participate has proven to be a very effective and common method of understanding leisure motivation (Beggs \& Elkins, 2010). Beard and Ragheb (1983) developed the leisure motivation scale, which includes four sub-scales: the intellectual dimension of motivation refers to mental stimulation, such as cognitive learning or the opportunity to use one's imagination; the social component refers to the need for interpersonal relationships; the competence/mastery factor explains motivation in terms of the desire for competition and challenge; the stimulus avoidance dimension refers to the escape and restoration one desires in leisure activities (Beggs \& Elkins, 2010). It should also be noted that leisure motivation may correspond to "sender" and/or "helper" in the Actant Model in this study.

\subsubsection{Satisfaction in Leisure Participation}

Leisure satisfaction has been found to contribute life satisfaction in many research studies (Korotkov, Mclean, \& Hamilton, 2011; Payne \& Zabriskie, 2014; Smith, Freeman, \& Zabriskie, 2009). The concept of leisure satisfaction which may be specified as the valuation of leisure experience (Ateca-Amestoy et al., 2008) was defined as the positive perception or feeling that an individual forms, obtains or gains as a result of participating in leisure (Agyar, 2014). Leisure satisfaction, in general, refers to the positive perception or feeling that an individual forms, elicits or even gains as a result of engaging in leisure (Beard \& Ragheb, 1980). Several variables have been linked to leisure satisfaction, such as personality, leisure activity or participation, leisure interest, facilitators and constraints to leisure. Additionally, engaging in leisure activity may have a positive influence on a variety of other outcomes, such as physical, emotional, spiritual and psychological well-being (Gillium, 2006; Schmidt \& Little, 2007).

Individuals may develop positive or negative leisure experiences, which may affect their leisure satisfaction in both the long- and short-term throughout their lifetimes. Gordon and Catalbiano (1996) indicate that leisure satisfaction during the college years has great importance as students develop leisure patterns and behaviors that have long-term implications for shaping leisure attitudes and behaviors in the following life-stages. As such, in examining the leisure behavior patterns over the lifetime, findings consistently indicate that family leisure is positively related to family functioning, cohesiveness, satisfaction with family life, healthy couple relationships, healthy relationships between parents and their children, and family strength (Mactavish \& Schleien, 2004; Poff, Zabriskie, \& Townsend, 2010; Zabriskie \& McCormick, 2001). However, in leisure, perceived freedom was another leisure structure related with life satisfaction (Poulsen, Ziviani, Johnson, \& Cuskelly, 2008) and subjective well-being (Kim, 2010). This concept has been considered as a key factor in leisure experience, and was explained as a state in which the person feels what she/he is doing is done by choice and because one wants to do it (Siegenthaler \& O'Dell, 2000). Thus, perceived freedom in leisure is a cognitive motivational construct mentioning participant's perceptions about leisure activities involved by his/her own choice. It is found that the individuals with high levels of perceived freedom in leisure perceive themselves to be competent and able to control not only what happens before and during participating in leisure activities but the benefits of the participation as well (Poulsen et al., 2008). In this vein, satisfying participation in leisure during individual's life span may be contributing her/him to develop psychological, physical and social well-being. It is to be added that leisure satisfaction in this study may also correspond to the "object" in the Actant Model. 


\subsubsection{Constraints in Leisure Participation}

Constraints were defined as factors that may inhibit activity participation or limit satisfaction (Jackson, 1988, 2005). They are likely to appear in the processing of leisure activities, including time, health, workload, interpersonal relationships and transportation. Leisure constraints were described by Crawford and Godbey (1987) as the factors in individuals' subjectively perceiving and generating disgust at or not participating in leisure activities. However, in leisure literature, the impact of technology as a social factor also had implications for women's leisure. Due to the highly gendered nature of digital gaming, many females remained less likely to participate (Crawford, 2005). The relationship of technology explicitly for women's leisure was a new area of study (Henderson \& Hickerson, 2007). Gibson et al. $(2003,2004)$ described how retired women resisted an ethic care because of their sense of entitlement to leisure. Likewise, Aslan (2004) found that Turkish women had constraints with their leisure as ethic of care. Although leisure has long been framed within the notion of time, the impact of time pressure on women's lives was analyzed related to the pace of society. By contrast, facilitators such as positive peer influence (Crawford et al., 1991) enable or promote participation or enjoyment (Aslan, 2002; Raymore, 2002). These factors may influence access to and opportunity for participation in leisure activity and satisfaction. Jackson $(1988,2005)$ indicated that leisure constraints referred to individual perception or experiences being constrained or influenced but that did not necessarily result in non-participation; instead, it would affect individual preferences for leisure activities, and further change the intention to participate.

Crawford and Godbey (1987) classified constraints in three categories: intrapersonal constraints, defined as the individual's psychological qualities affecting the development of leisure preferences; interpersonal constraints, defined as social factors affecting development of leisure preferences, and structural constraints that include factors intervening between the development of leisure preferences and participation. In a study, Crawford, Jackson, and Godbey (1991) presented their hierarchical model of leisure constraints as intrapersonal and interpersonal constraints affecting leisure preferences, whereas structural constraints intervene between preference and participation.

However, constraints do not always result in nonparticipation; rather, constraints once encountered might be overcome or negotiated (Crawford et al., 1991; Kay \& Jackson, 1991; Jackson et al., 1993; White, 2008). The researchers found that in financial constraints, participants saved money and chose less expensive activities; in time constraints, they arranged the time spent both at home and at work. Jackson et al. concluded that leisure participation is dependent not on the absence of constraints, but on negotiations about them (White, 2008). In their study, Jackson and Rucks (1995) grouped negotiation strategies as changing interpersonal relations, skill acquisition, time management, changing leisure aspirations, and rearranging finances. As such Walker and Virden (2005) indicated several constraints which scored high on scales across studies, including lack of information, lack of time, and distance to recreation facilities, crowding, high costs, and family commintments. They stated that constraints to outdoor recreation were similar to other leisure activities. It should also be observed that within the framework of the Actant Model in this study leisure constraints may correspond to the "opponent".

\section{Method}

\subsection{Sample}

The universe of the study covers 150 prospective classroom teachers who were the fourth grade undergraduates in the Faculties of Education in Izmir. In this vein, a convenience sample was taken by purposive sampling methods in qualitative research. The reason is that both of the researchers were the academicians of this Faculty. The participants of this study were the fourth grade undergraduates in the Faculty of Education in Ege University in Izmir, Turkey. In the process of fixing the sample, the thematic duplications were taken into consideration. This was carried on until the thematic duplications were structured, and was framed with 47 prospective teachers ( 25 female and 22 male) between the ages of 21 to $22(\mathrm{M}=21.5)$.

\subsection{Instrument}

It was preferred to use the interview technique for qualitative data analysis to assess the social facts related to the issues in this study. The formulation of the interview questions was therefore based on obtaining the basically needed data. Brannigan (1985) states that the structured interview approach gives the opportunity to compare the participants' statements with the similarities and differences in their explanations. For this reason, the structured interview approach was preferred in this study.

It was determined that the Greimas' Actant Model was the most explanatory one to analyze the data of this study. By considering the characteristics of the sample, the interview questions were designed as comprehensible as 
possible, framing the goals of the research and excluding any intrusive supportive views. A pool of questions was then developed from which the most suitable interview questions were be selected. The most appropriate contributions focusing on the aim of the research were chosen by two experts who were familiar with the Actant Model. The selected questions structured the interview form. Although the questions were prepared with an intense effort, it was foreseen that some of them could have been misinterpreted by some participants. For such cases, the researcher should have some alternative or probe questions to make the meaning clear. Alternative questions, therefore, are anticipated so as to ask the same questions in a different manner. Consequently, the probes are for making the meaning clearer and understandable (Yıldırım \& Şimşek, 2011, p. 133). Similarly, alternative questions and probes were structured for the interview form as well, which encompasses the following types of questions:

1) Do you participate in leisure activities in the faculty and the campus?

Probes:

a) If you participate, why?

b) If you don't participate, why?

2) Are you supported/motivated to participate in these activities? If so, how?

Alternative question:

- Is there anybody or anything motivating you in your participation? If so, who/what are they?

3) Do you have any barriers/constraints to participate in leisure activities? If so, what are they?

4) What advantages or achievements do you think you will gain with your participation in leisure activities?

\subsection{Pilot Study}

The pilot study to determine the interview form was completed with 7 preservice teachers ( 4 female, 3 male) who were not included in in-depth interviews. At the end of this process, the researchers decided that the interview form was adequate in language and clarity for interpretation by the participants.

\subsection{Procedure}

The in-depth interviews were carried out in April, 2015. It was explained to the participants that the interviews would be implemented in an informal environment, they could speak freely and comfortably, and there would be no rights or wrongs. They were also informed about the importance of tape recording, and their consent for it was requested and obtained. The researchers conducted the in-depth interviews themselves, lasting 45 minutes each, and taking notes as needed.

\subsection{Analysis}

In the analysis, Greimas' Actant Model was used (Culler, 2002; Hébert, 2011). Within this framework, "individual happiness" and "self actualizing" were considered to be the object, and preservice teachers to be the subject expected to conjoin the object in this study. The following questions are an example of those constructed within the framework of Greimas' Actant model:

-What are the helpers and opponents of the preservice teachers in conjoining the object?

-What may be the results of conjunction or disjunction?

-Who/what benefits from this situation?

After completing the in-depth interviews with the participants, the data were grouped by gender. The interview records were written down by the researchers themselves in order not to overlook any details. The qualitative data set during this process is shown in Table 1.

Table 1. Qualitative data set

\begin{tabular}{lllcl}
\hline Technique of gathering data & Source of data & Material & Time to write the data down & Data set \\
\hline In-depth interviews & $\begin{array}{l}\text { Preservice } \\
\text { teachers }\end{array}$ & $\begin{array}{l}47 \text { audio } \\
\text { files }\end{array}$ & 284 hours & 157 pages \\
& & & \\
\hline
\end{tabular}

Audio files were obtained as per Table 1 for each participant, totaling 47 audio files, covering 157 papers. Each audio file was individually evaluated and recorded, which took 46 days. The next step was to analyze each 
record independently, reading it 2 or 3 times and at different times. During this process, the coding was done within the framewok of the 6 Actants in Greimas' Actant Model. Table 2 shows how the coding was done.

Table 2. Coding of qualitative data set

\begin{tabular}{ll}
\hline M2: Male student, Number 2 & Date: $02.04 .2015 / 11.20$ a.m. \\
\hline I have hardly any friends who participate in leisure & It is considered that; for the prospective \\
activities in my school group. Besides, the information & teacher, the lack of friend/friends \\
for the activities are not organized well, which hinders & participating in leisure activities; and also \\
my participation. & $\begin{array}{l}\text { the insufficiency of the information on the } \\
\text { leisure activities, build a "barrier" for him. }\end{array}$ \\
\hline
\end{tabular}

Miles and Huberman's (1994) measurements were used to ensure the reliability and validity of the research. To achieve the internal validity, the key concepts of the research were focused on, and the interview questions were designed in relation to the literature. The prospective teachers' views were quoted and explained. The findings were compared to other studies in the literature. To understand whether the explanations of the findings were meaningful, they were either explained by induction or deduction within the framework of the components of the Actant Model. Moreover, to obtain the external validity, the method, the characteristics of the participants, the characteristics of data collection instruments, and the developmental process were defined in detail. After coding the interview statements on the basis of the 6 elements of the Actant Model, two experts were used to code them again within this framework. Next, the disagreements between the researchers and the experts were solved, and the percent of compromise which Miles and Huberman (1994) advised were calculated. Thus, with the Formula of "compromise percent $=[$ agreement $/ \mathrm{Na}$ (agreement $)+\mathrm{Nd}$ (disagreement) $]$ x 100", the conformity was found to be $89 \%$.

\section{Findings}

The analyses of the in-depth interviews based on Greimas' Actant Model are provided in Figure 2 for the female prospective teacher participants, and in Figure 3 for the male ones. 
Sender

Object

-desire, interest

-desire of self-actualizing

-feeling happiness

- be with friends

-desire to enjoy the university life

- enjoy the activity -happy and self-satisfied individual -more aware and self-confident individual

-achievement of a different perspective of life

-develop occupational skills and abilities

-personal development

- socializing, enjoy the time with

friends, having new friends
Receiver

prospective teacher

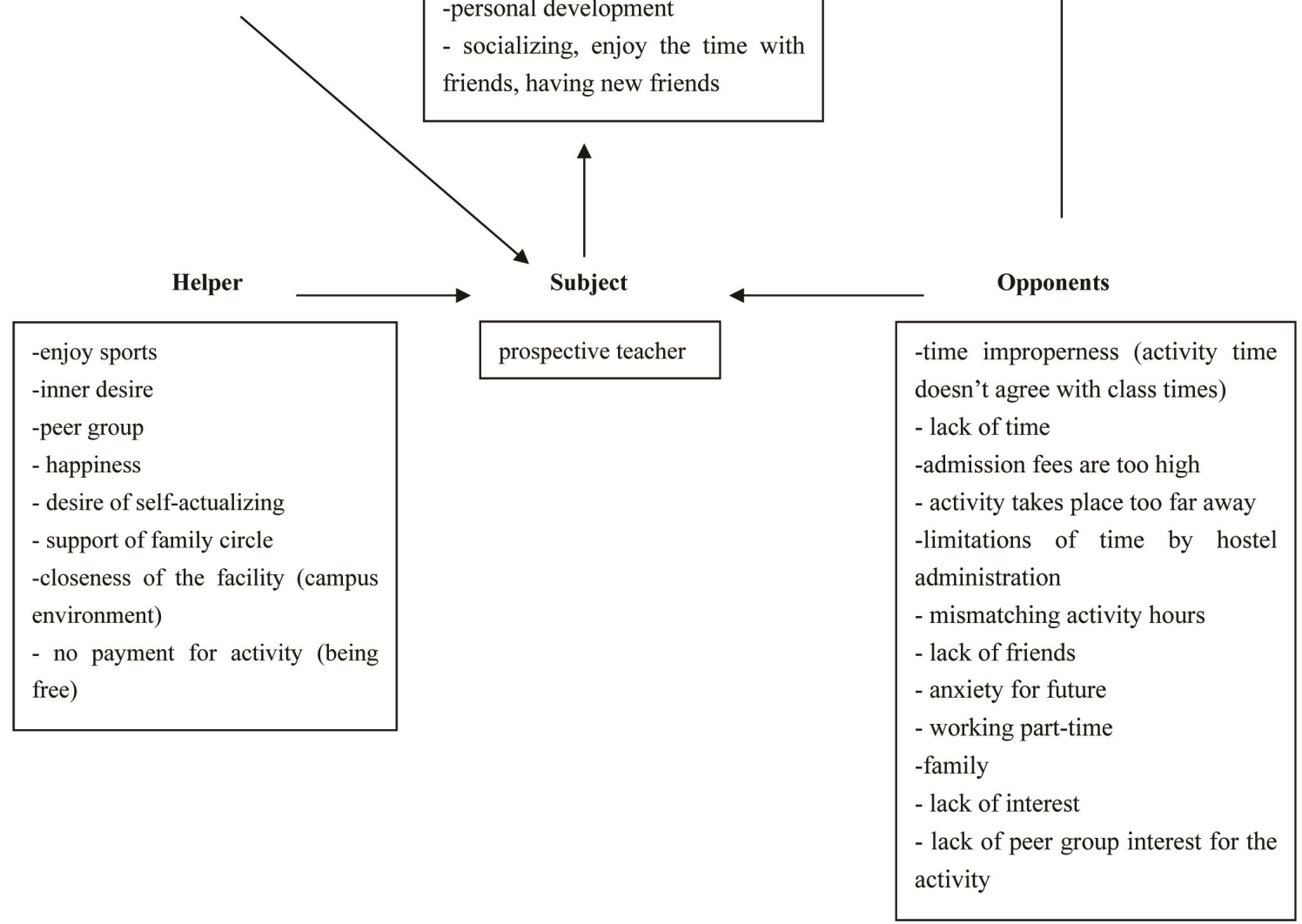

Figure 2. Modelling of female prospective teachers' interviews 


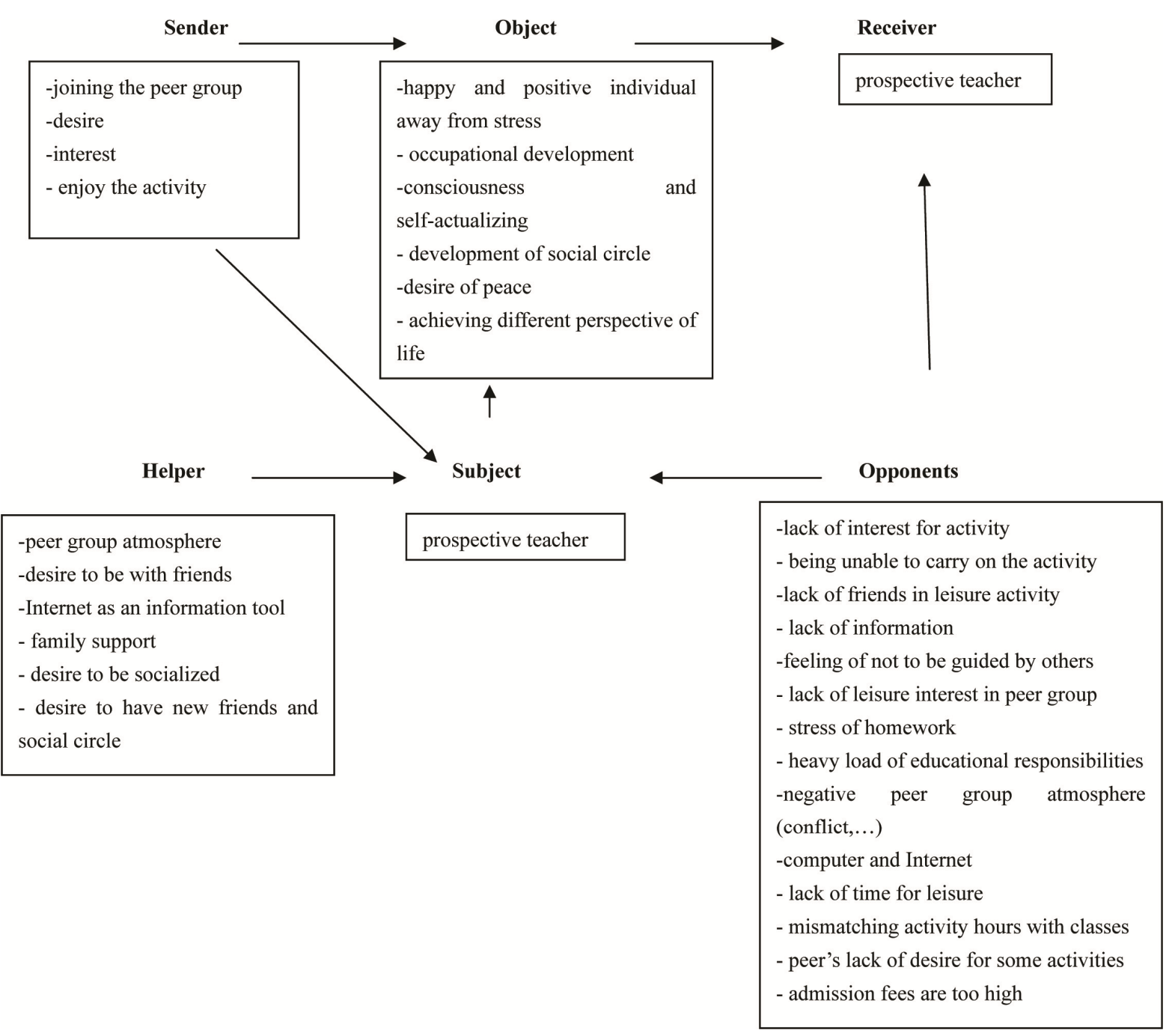

Figure 3. Modeling of male prospective teachers' interviews

\subsection{The Subject for Prospective Teachers}

This study was structured on the helpers and opponents encountered by the prospective teachers while processing the attainment of the research object. Therefore, the subject was the "prospective teacher". Being informed that their age group was the subject of the research; they gave examples from their lives:

"I participate in leisure activities to have good time to become socialized, to get to know myself better." (F12)

"The feeling of happiness I have in leisure is motivating me positively to go on." (M8)

\subsection{The Object for Prospective Teachers}

Within the framework of the research, "gaining individual fulfillment and self-actualizing" was identified as the object. The interviewees had focused on their aims at leisure activity participations, and the reflection of these participations in their lives. The findings indicated that the prospective teachers participated in leisure activities "to be happy and positive to get away from stress, to be self-actualized and aware individual", "to have a different viewpoint", "individual and occupational development", "to gain an inner peace", "to have good time with friends", and "to have a new social circle".

Following are examples:

"To participate in leisure activities gives me a sense of fulfillment of life, and happiness. Turns me into an aware person." (F1)

"The leisure activities I participated in gave me a chance to socialize, to have new friends and enjoy my time with them." (M1) 
"I really had the benefits of these activities by enriching self-confidence." (F4)

"In fact, the feeling of doing something only for your own sake is very important." (F5)

"I participate in leisure activities to gain a different viewpoint, to strengthen the communication with others, to have individual happiness and to develop my occupational skills and abilities.” (F2)

"Leisure activities contribute to develop the self in many ways, to be a social person and to have a better planned life." (M1)

"I want to participate in leisure activities to be relaxed, to feel positive, to be social, to have good communication skills and to feel like a university student." (M6)

\subsection{The Helper for Prospective Teachers}

Interviewees mentioned that many helpers supported and motivated their leisure participation. The initial points were "enjoyment of" and "interest in the activity".

Following are examples:

"I am interested in folk dancing so I decided to participate in the activity." (F1)

"Basically, enjoyment and the desire I have and the sincerity of the friends are very important in my participation." (F3)

Friends and peer group "effect" were found to be another chief helper for both female and male prospective teachers.

Following are examples:

"If I enjoy the activity and feel good, I keep on participating. During these times, being with my friends makes me very happy. If I go alone, I don't enjoy the activity. I want to have a university life full of satisfaction." (F4)

"My friends' participation in any activity makes me join them." (M9)

"My peer group takes me to some different activities. We enjoy being together." (F7)

"If my peer group participates in the activity, I want to join them immediately." (M6, M3)

"I participate in the activity only if I can be with my friends there." (M7, M2)

Availability of the leisure activity by closeness, being inexpensive or free, the suitable hours/periods-for the interviewees had great importance as well.

Following are examples:

"I love joining the activities on campus because of the closeness." (F10)

"If the activity is free or cheap, and doesn't last into late hours, it motivates me to join." (F12)

"I participate in the activity because it matches with my class-periods." (F2)

Some of the interviewees mentioned the guidance of their mothers, fathers or some other relatives.

Following are examples:

"My father is the great supporter for me in my participation in folk dancing." (F5)

"My family and aunts encouraged me to play an instrument." (F4)

"My mother wanted me to be in the folk dancing activity, and I started. Now, I love it." (M3)

\subsection{The Opponents for Prospective Teachers}

Both female and male prospective teachers declared a number of opponents/constraints in their participation in leisure activities.

For example, the mismatching of the hours of the activity with their class periods was the basic one:

"I wanted to join the drawing club, but its hours didn't fit my class periods." (F1)

"I cannot participate in some activities I desired because of the mismatching hours, and also the heavy work load." (F2)

Another important constraint was mentioned to be the high cost of the fees, which may be a structural constraint.

Following are examples:

"If the admission fees are high, I give up joining the activity." (F9, F7) 
"Because of my limited budget, I am unable to participate in activities that need fees." (F12)

"High admission fees are the barriers for my participation in activities." (M7, M8)

The leisure activities that start in late hours and in faraway locations structurally prevent the participation of the interviewees.

"I cannot participate in late-hour activities, and faraway distant ones." (F6, F9)

"If the activity is far from where I live, I don't participate." (M5, M7)

"I am unable to join the activities that are far from my hostel because we must obey the official hours." (F3)

The reasons for lack of time were mentioned by the interviewees basically as intrapersonal constraints for non-participation:

"I cannot find time for leisure activities because of my intense academic studies." (F5, F6)

"Because of my courses and responsibilities in the Faculty, my regular leisure activities and my part-time work, I am unable to join in some other leisure activities." (F9)

"I am negatively affected by my work load in the Faculty." (M8)

"I work part-time so I have very little time for leisure. I feel so tired. Although I want to attend Latin American dance courses and to play sports on campus, it is impossible for me." (F10)

Another important opponent stated among the interviewees was interpersonal constraints, as "Lack of companions to join, or companions prefer other things." These types of interpersonal constraints were commonly mentioned by the male prospective teachers.

Following are examples:

"If my friends don't participate in the activity, I don't want to, either." (M2, M4, M5, M12)

"If my companions aren’t interested in these activities, I give up." (M1, M8)

“'One of my problems is that my peer group isn't interested in such activities. I participate alone, but don't enjoy it much." (F10)

"If I don't feel comfortable within the activity group (football, basketball), I stop participating." (M6)

Some of the male interviewees mentioned that their interest in the computer and internet were a reason for their non-participation in leisure activities.

Following are examples:

"Because of the popularity of the Internet in our daily lives, we spend much of our time with it. Thus, we are limited in joining regularly some activities." (M2, M4)

To summarize, it was clearly identified that male interviewees stated more constraints compared to females. Male interviewees gave up the activity when they had a barrier, but females tried to find some grounds for negotiating.

Following are examples:

"I live in Izmir with my family. When I started the University, I used to have my classes in the Faculty and come back home, just as my routine in high school. The reason was that my family didn't let me do anything else. One day, I decided to talk with my parents to explain to them that I wanted to develop my skills and abilities and gain a sense of self-confidence as a university student. This worked. I had convinced them. Though I am not free as my friends who are not living with their families, I became the university student I desired." (F11)

"I live with my grandma. My hours to stay out are limited. Thus, I couldn't join some of the leisure activities I wanted. I explained this to her and got her permission. Now, I can use my time more flexibly." (F7)

\subsection{The Sender for Prospective Teachers}

In this study, it was found out that the sources of motivation for leisure activities of interviewees were "desire and interest", "develop the skills and abilities", "enjoy the activity", "feeling of happiness", "be with friends", "join the peer group", and "desire to experience a fulfilling university life".

Following are examples:

"If the activity interests me and gives me satisfaction, I definitely participate." (M6)

"Now, I play the flute which I wanted to since my childhood. Folk dancing is my companions' advice. And I 
always loved playing sports." (F1)

"My peer group environment is very important to me to keep up my participation in an activity." (M3)

\subsection{The Receiver for Prospective Teachers}

Within the framework of the current research, the receiver is the one who has achieved self-satisfaction by self-actualizing. That is to say, it is the prospective teacher "himself/herself" as follows.

"The leisure activities I participate in are positively affecting my perspective, my self-confidence and my imagination. I find another self after the activity." (F6)

"I participate in activities to feel positive, to socialize, to have better communication with my companions, to relax and to feel like a university student." (M1, M6)

"When I join the activity, I feel happy." (M8)

"I think these activities I participate in develop my self-confidence." (F4)

"The ability to criticize the world-wide events and also to have an interest in different subjects are all related to how you spend your leisure time. The more we achieve, the more we gain in self-confidence. Besides this, we become socialized and become a more tolerating individual." (F8)

"The more I participate, the better I feel. I believe I do something useful." (F2)

"Leisure activities give me the chance to relax, satisfaction in my life, make me aware and also bring happiness. I feel that I am making an investment in my future by participating in leisure activities." (F1)

\section{Discussion and Conclusion}

The current research on leisure participation activities of the Prospective Teachers within the framework of Greimas' Actant Model provides important insight into leisure literature. Owing to the fact that this research study is unique because it applies the Actant Model to leisure literature, it has been difficult to find a similarly supportive study among the leisure research. However, some indicators, as in White's study (2008), were found to be very similar regarding motivation, constraints and negotiation. Sender, Helper and Object in this research may be thought to have similarities with motivation, and the opponents with constraints, as in Whites' study (p. 350).

To explain the results within the framework of the Actant Model, Sender, Helper and Object function as motivation, contributing to the participation in the activity by the subject, who is the prospective teacher. Notably, females are found to have more motivation and desire than males in leisure participation. For females, Sender and Helper supported the object more strongly, promoting their participation in leisure. They may have more awareness of the achievement of being a university student, and also of the opportunities of the campus and the metropolitan city in which they live. Motivation, in the form of desire, interest, happiness and socializing with friends for satisfying leisure experiences, had a relatively stronger impact in participation for females than males. Thus, while sender and helper similarly and strongly support the object in this study, the receiver or the subject also join the desired activity.

In addition to the motivation of enjoyment, happiness and sociability, the prospective teachers' aim in leisure participation was said to develop their occupational talents and skills. This is appreciated by the researchers since these young people will be models for the children they will teach in the future. Furthermore, the results suggest the role of opponents as constraints in leisure participation of the prospective teachers. More opponents were declared by males than females. As central opponents by males were mentioned "lack of interest and lack of peers to join the activity". Some researchers framed leisure constraints in terms of barriers to recreation activity participation (Buchanan \& Allen, 1988; Searle \& Jackson, 1985b), assuming that encountering barriers necessarily resulted in nonparticipation. Jackson (1988) defined the constraints as factors that may inhibit the activity participation or limit satisfaction. For Crawford and Godbey (1987), constraints affected not only participation but also the acquisition of leisure preferences. They grouped the constraints in three categories as intrapersonal, interpersonal and structural. In the following studies, researchers noted that intrapersonal and interpersonal constraints affect leisure preferences, while structural constraints intervene between preferences and participation (Crawford, Jackson, \& Godbey, 1991).

In our study, males commonly referred to intrapersonal (e.g., lack of interest, desire and time) and interpersonal (e.g., lack of leisure interest with peer group) constraints as well as a few structural constraints (e.g., admission fees are high, mismatching activity hours). On the other hand, females reported less constraints or opponents than males, and they were mostly structural (e.g., activity time doesn't suit; too far; lack of time). Considering 
that constraints may have a direct negative effect on activity participation, as per White (2008), in our study also few male interviewees noted the engagement in leisure activity participation. Furthermore, in the male group the sender and helper as motivation contributed the most to the socialization of the subject.

However, for female interviewees, the motivations were structured not only on being socialized but on emotional factors as well. This may demonstrate that they had a stronger motivation for participating in leisure activities, which they did. Furthermore, the females declared less opponents/constraints. Some of them explained that they negotiated when problems arose with their activity participation, and this increased their self-confidence. However, none of the males mentioned negotiation. The higher motivation to participate of the females is likely to encourage the use of negotiation strategies or resources to overcome opponents. White (2008) states that negotiation efficacy encourages motivation, diminishes the perception of constraints, and encourages the use of negotiation efforts that result in an indirect positive influence on leisure participation, whereas constraints or opponents exhibited a direct negative influence on participation.

In conclusion, the results suggest a central role for gender in leisure participation within the traditional norms and values in society. Being brought up in a gendered society where the roles are strictly distinguished, females have limitations and social pressure regarding acting or doing something by themselves. When they find the opportunity to be a university student, they feel partly privileged, and comparatively free to self-actualize. And still they need to get the approval of their parents to join some activities during their university life. If they live away from their parents, it is easier to create the accomplishment of a goal as a target in life. One of the targets is thought to be a social, self-satisfied and aware individual as a university student who is going to be a teacher modeling for the students as a capable, talented teacher in the future. The female interviewees explained this "between the lines" during the sessions. These females' desire to struggle for greater freedom of action in this traditionally structured society contains a greater awareness of the value of a leisure participation in which they achieve new perspectives and skills, a feeling of achievement and self-satisfaction, and an awareness of the need to break the chains around them. They appreciate the opportunities they are furnished by leisure to contribute to explore within themselves, and gain self-confidence as individuals.

On the other hand, males are socialized to be independent and authoritarian in traditional Turkish society, and they tend to participate rarely in leisure activities (Aslan, 2005, 2009). These facts provide support to the results of our research. It can therefore be readily understood that they don't have much awareness of the contribution of leisure participation for them, which results in their rare participation in leisure activities, and more opponents that they never thought to be able to negotiate. It is recommended, and hoped for, that starting from the family and later in schools, gender discrimination in socialization will become weaker; the new generations should be educated to be aware of the importance of leisure to become a modern contemporary individual. As a long-lasting target, leisure is expected to be carried out as a social and educational project supported by the government. And nonetheless, the university and faculty administrations should urgently rearrange their schedules to leave time for their students to participate in leisure activities; increase the quality and quantity of leisure guides; maintain more opportunities and facilities for leisure, and encourage students to use them. It has to be understood as well during this developmental process of Turkish society that leisure awareness can only be truly developed and internalized by both informal and formal education.

It is our hope, then, that this study is making some significant contributions to the literature. It assessed the leisure participation of prospective teachers in the Education Faculty at Ege University by utilizing the Actant Model, which made it the only leisure research study applying the aforementioned model in Turkey. Future research will be carried out to identify the reasons for opponents in a revised in-depth interview using the same Greimas' method.

One limitation of this study is that the interviewees were already in the fourth year at the university. If prospective teachers were interviewed each year, starting from the second year, it would be possible to develop a longitudinal study, which would be more informative about the leisure participation and behavior of prospective teachers.

\section{References}

Agate, J. R., Zabriskie, R. B., Agate, S. T., \& Poff, R. (2009). Family leisure satisfaction and satisfaction with family life. Journal of Leisure Research, 41(2), 205-223.

Agyar, E. (2014). Contribution of perceived freedom and leisure satisfaction to life satisfaction in a sample of Turkish women. Social Indicators Research, 116, 1-15. http://dx.doi.org/10.1007/s11205-013-0268-0

Arslan Cansever, B. (2010). Ergenlerin internet kullaniminin aile ve okul baglaminda yarattigi sorunlar [The 
problems of teen-age socialization related to spending time on the Internet from the perspectives of family and school] (Unpublished doctoral dissertation). Izmir: Sosyal Bilimler Enstitusu.

Aslan, N., \& Arslan Cansever, B. (2012). Ergenlerin boş zaman değerlendirme algıs1 [Leisure perceptions of adolescents]. Hacettepe Üniversitesi Eğitim Fakultesi Dergisi, 42, 23-35.

Aslan, N. (2002). The impact of leisure constraints on leisure participation. Ege Egitim Dergisi, 1(2), 11-24.

Aslan, N. (2004). Gender, women and leisure-A study on Turkish women. In M. Kaila et al. (Eds.),

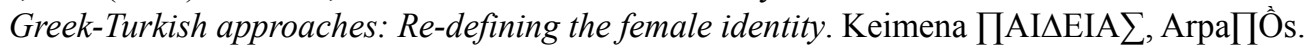

Aslan, N. (2005). Üniversite ögrencilerinin boş zaman değerlendirme eğilimi: Oğretmen yetiştiren kurumlarda karşılaştırmalı bir araştırma (Leisure tendencies of university students: A comparative study) (2nd ed.). Izmir: E.U. Eğitim Fakültesi Yayınları.

Aslan, N. (2009). An examination of family leisure and family satisfaction among traditional Turkish families. Journal of Leisure Research, 41(2), 157-176.

Beard, J. G., \& Ragheb, M. G. (1980). Measuring leisure satisfaction. Journal of Leisure Research, 12(1), 20-33.

Beard, J. G., \& Ragheb, M. G. (1983). Measuring leisure motivation. Journal of Leisure Research, 15(3), 219-228.

Beggs, B. A., Elkins, D. J., \& Powers, S. (2005). Overcoming barriers to participation in campus recreational sports. Recreational Sports Journal, 29(2), 143-155.

Beggs, B. A., \& Elkins, D. J. (2010). The influence of leisure motivation on leisure satisfaction. The Cyber Journal of Applied Leisure and Recreation Research. Retrieved from http:// larnet.org/2010-02.html

Brannigan, G. G. (1985). The research interview. In A. Tolor (Ed.), Effective interviewing. Springfield, IL: Charles C. Thomas Publication.

Buchanan, D. R., \& Allen, L. (1988). Barriers to recreation participation in later life cycle stages. Therapeutic Recreation Journal, 19, 39-50.

Chick, G. (1998). Leisure and culture: Issues for an anthropology of leisure. Leisure Sciences, 20, 111-133. http://dx.doi.org/10.1080/01490409809512269

Chen, Y. C., Li, R. H., \& Chen, S. H. (2013). Relationships among adolescents' leisure motivation, leisure involvement, and leisure satisfaction: A structural equation model. Social Indicators Research, 110, 1187-1199. http://dx.doi.org/10.1007/s11205-011-9979-2

Crawford, G. (2005). Digital gaming, sport and gender. Leisure Studies, 24, 259-270. http://dx.doi.org/10.1080/0261436042000290317

Crawford, D. W., \& Godbey, G. (1987). Reconceptualizing barriers to family leisure. Leisure Sciences, 9(2), 127-199. http://dx.doi.org/10.1080/01490408709512151

Crawford, D. W., Jackson, E., \& Godbey, G. (1991). A hierarchical model of leisure constraints. Leisure Sciences, 13(4), 309-320. http://dx.doi.org/10.1080/01490409109513147

Culler, J. (2002). Structuralist poetics. London: Routledge Classics.

Freysinger, V. J., \& Kelly, J. R. (2000). 21 st century leisure: Current issues. Boston, MA: Allen \& Bacon.

Gibson, H., Ashton-Schaeffer, C., Green, J., \& Autry, C. (2003). Leisure in the lives of retirement-aged women: Conversations about leisure and life. Leisure/Loisir, 28(3-4), 203-230. http://dx.doi.org/10.1080/14927713.2003.9651313

Gillium, R. (2006). Frequency of attendance at religious services and leisure-time physical activity in American woman and men: The third national health and nutrition examination survey. Religiousness and Physical Activity, 31, 30-35.

Gordon, W. R., \& Catalbiano, M. L. (1996). Urban and rural differences in adolescent self-esteem, leisure boredom, and sensation-seeking as predictors of leisure time usage and satisfaction. Adolescence, 31, 883-901.

Hébert, L. (2011). Tools for text and image analysis: An introduction to applied semiotics. Retrieved from http://www.signosemio.com/documents/Louis-Hebert-Tools-for-Texts-and-Images.pdf

Henderson, K. A., \& Hickerson, B. (2007). Women and Leisure: Premises and Performances Uncovered in an Integrative Review. Journal of Leisure Research, 39(4), 591-610. 
Hodge, C. J., Zabriskie, R. B., Fellingham, G., Coyne, S., Lundberg, N. R., Padilla-Walker, L. M., \& Day, R. D. (2012). The relationship between media in the home and family functioning in context of leisure. Journal of Leisure Research, 44(3), 285-307.

Jackson, E. L. (1988). Leisure constraints: A survey of past research. Leisure Sciences, 10, 203-215. http://dx.doi.org/10.1080/01490408809512190

Jackson, E. L., Crawford, D. W., \& Godbey, G. (1993). Negotiation of leisure constraints. Leisure Sciences, 5(1), 1-11. http://dx.doi.org/10.1080/02614368600390011

Jackson, E. L., \& Rucks, V. C. (1995). Negotiation of leisure constraints by junior-high and high school students: An exploratory study. Journal of Leisure Research, 27(1), 85-105.

Jackson, E. L. (Ed.). (2005). Constraints to leisure. State College, PA: Venture Publishing.

Jacobs, K., \& Jacobs, L. (2001). Quick reference dictionary for occupational therapy. Thorofare, NJ: Slack.

Kay, T., \& Jackson, G. (1991). Leisure despite constraint: The impact of leisure constraints on leisure participation. Journal of Leisure Research, 23(4), 301-313.

Kim, B. (2010). A conceptual framework for leisure and subjective well-being. International Journal of Tourism Sciences, 10(2), 85-116. http://dx.doi.org/10.1080/15980634.2010.11434627

Korotkov, D., Mcbean, H., \& Hamilton, L. (2011). Predicting leisure satisfaction: A comparative analysis of the agency and communion model with the five-factor model of personality. The American Association Behavioral and Social Sciences Journal, 15.

Liu, H., Yeh, C. K., Chick, G. E., \& Zinn, H. C. (2008). An explanation of meanings of leisure: A Chinese perspective. Leisure Sciences, 30, 482-488. http://dx.doi.org/10.1080/01490400802353257

Lu, L., \& Hu, C. H. (2005). Personality, leisure experiences and happiness. Journal of Happiness Studies, 6(3), 325-342. http://dx.doi.org/10.1007/s10902-005-8628-3

Lu, L., \& Kao, S. F. (2009). Direct and indirect effects of personality traits on leisure satisfaction: Evidence from a national probability sample in Taiwan. Social Behavior and Personality, 37(2), 191-192. http://dx.doi.org/10.2224/sbp.2009.37.2.191

Mactavish, J. B., \& Schleien, S. J. (2004). Re-injecting spontaneity and balance in family life: Parents' perspectives on recreation in families that include children with developmental disability. Journal of Intellectual Disability Research, 48(2), 123-141. http://dx.doi.org/10.1111/j.1365-2788.2004.00502.x

Miles, M. B., \& Huberman, A. M. (1994). An expanded sourcebook qualitative data analysis. Thousands Oak, California: Sage Publications.

Parsa, S., \& Parsa, A. F. (2004). Göstergebilim çözümlemeleri. İzmir: Ege Üniversitesi Basımevi.

Payne, L., \& Zabriskie, R. (2014). Understanding the Role of Leisure in Life Transitions. Journal of Park and Recreation Administration, 32(1), 1-6.

Poff, R., Zabriskie, R., \& Townsend, J. (2010). Modeling family leisure and family related constructs: A national study of U.S. parent and youth perspectives. Journal of Leisure Research, 42(3), 365-391.

Poulsen, A. A., Ziviani, J. M., Johnson, H., \& Cuskelly, M. (2008). Loneliness and life satisfaction of boys with developmental coordination disorder: The impact of leisure participation and perceived freedom in leisure. Human Movement Science. http://dx.doi.org/10.1016/j.humov.2008.02.004

Raymore, L. (2002). Facilitators to leisure. Journal of Leisure Research, 34, 37-51.

Robert, A. S. (2001). The costs and benefits of hedonism: Some consequences of taking casual leisure seriously. Leisure Studies, 20(4), 305-309. http://dx.doi.org/10.1080/02614360110086561

Sayın, Ö. (2014). Göstergebilim ve sosyoloji. Ankara: Anı Yayıncılık.

Schmidt, C., \& Little, D. (2007). Qualitative insights in leisure as a spiritual experience. Journal of Leisure Research, 39, 222-247.

Searle, M. S., \& Jackson, E. L. (1985b). Socioeconomic variations in perceived barriers to recreation participation among would-be participants. Leisure Sciences, 7, 227-249. http://dx.doi.org/10.1080/01490408509512120

Searle, M. S., Mactavish, J. B., \& Brayley, R. E. (1993). Intergrating ceasing participation with other aspects of leisure behavior: A replication and extension. Journal of Leisure Research, 25(4), 389-404. 
Shaw, S. M., \& Henderson, K. (2005). Gender analysis and leisure constraints: An uneasy alliance. In E. L. Jackson (Ed.), Constraints to Leisure (pp. 23-34). State College, PA: Venture Publishing, Inc.

Siegenthaler, K. L., \& O’Dell, J. (2000). Leisure attitude, leisure satisfaction and perceived freedom in leisure within family dyads. Leisure Sciences, 22(4), 281-296. http://dx.doi.org/10.1080/01490409950202302

Smith, K., Freeman, P., \& Zabriskie, R. (2009). An examination of family communication within the Core and Balance Model of Family Leisure Functioning. Family Relations, 58, 79-90. http://dx.doi.org/10.1111/j.1741-3729.2008.00536.x

Tsai, E. H. L., \& Coleman, D. J. (2009). The influence of constraints and self-efficacies on participation in regular active recreation. Leisure Sciences, 31, 364-383. http://dx.doi.org/10.1080/01490400902988309

Vardar, B. (2002). Açılklamalı dilbilim terimleri sözlüğü. Istanbul: Multilingual.

Walker, G. J., \& Virden, R. J. (2005). Constraints on outdoor recreation. In E. L. Jackson (Ed.), Constraints to leisure to leisure (pp. 201-219). State College, PA:Venture Publishing, Inc.

White, D. D. (2008). A structural model of leisure constraints negotiation in outdoor recreation. Leisure Sciences, 30, 342-359. http://dx.doi.org/10.1080/01490400802165131

Yıldırım, A., \& Şimşek, H. (2011). Sosyal bilimlerde nitel araştırma yöntemleri [Qualitative research methods in social sciences] (6 th ed.). Ankara: Seçkin Yayınları.

Zabriskie, R. B., \& McCormick, B. P. (2001). The influences of family leisure patterns on perceptions of family functioning. Family Relations, 50, 281-289. http://dx.doi.org/10.1111/j.1741-3729.2001.00281.x

\section{Copyrights}

Copyright for this article is retained by the author, with first publication rights granted to the journal.

This is an open-access article distributed under the terms and conditions of the Creative Commons Attribution license (http://creativecommons.org/licenses/by/3.0/). 